Article

\title{
Occurrence of $P$. aeruginosa in Water Intended for Human Consumption and in Swimming Pool Water
}

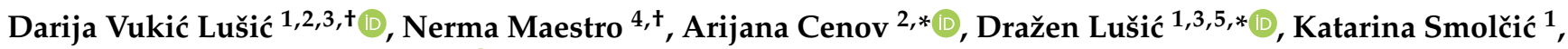 \\ Sonja Tolić ${ }^{6}$, Daniel Maestro ${ }^{7,8}\left(\mathbb{D}\right.$, Damir Kapetanović ${ }^{9}$, Sandra Marinac-Pupavac ${ }^{2}$, Dijana Tomić Linšak ${ }^{1,2}$, \\ Željko Linšak ${ }^{1,2}$ and Marin Glad ${ }^{2, *}$
}

Citation: Vukić Lušić, D.; Maestro, N.; Cenov, A.; Lušić, D.; Smolčić, K.; Tolić, S.; Maestro, D.; Kapetanović, D.; Marinac-Pupavac, S.; Tomić Linšak,

D.; et al. Occurrence of P. aeruginosa in Water Intended for Human

Consumption and in Swimming Pool Water. Environments 2021, 8, 132. https://doi.org/10.3390/ environments8120132

Academic Editor:

Helvi Heinonen-Tanski

Received: 29 October 2021

Accepted: 22 November 2021

Published: 24 November 2021

Publisher's Note: MDPI stays neutral with regard to jurisdictional claims in published maps and institutional affiliations.

Copyright: (c) 2021 by the authors. Licensee MDPI, Basel, Switzerland. This article is an open access article distributed under the terms and conditions of the Creative Commons Attribution (CC BY) license (https:// creativecommons.org/licenses/by/ $4.0 /)$.
1 Department of Environmental Health, Faculty of Medicine, University of Rijeka, Braće Branchetta 20, 51000 Rijeka, Croatia; darija.vukic.lusic@uniri.hr (D.V.L.); katarinasmolcic26@gmail.com (K.S.); dijanatl@uniri.hr (D.T.L.); zeljko.linsak@zzjzpgz.hr (̌̌.L.)

2 Department of Environmental Health, Teaching Institute of Public Health of Primorje-Gorski Kotar County, Krešimirova 52a, 51000 Rijeka, Croatia; sandra.marinac@zzjzpgz.hr

3 Center for Advanced Computing and Modeling, University of Rijeka, 51000 Rijeka, Croatia

4 Department of Communal Hygiene, Institute for Public Health of Canton Sarajevo, Dr. Mustafe Pintola 1, Ilidža, 71000 Sarajevo, Bosnia and Herzegovina; nerma.maestro@zzjzks.ba

5 Faculty of Health Studies, University of Rijeka, Viktora Cara Emina 5, 51000 Rijeka, Croatia

6 Department of Environmental Protection and Health Ecology, Andrija Štampar Teaching Institute of Public Health, Mirogojska cesta 16, 10000 Zagreb, Croatia; sonja.tolic@stampar.hr

7 Department of Environmental Health, Institute for Public Health of the Federation of Bosnia and Herzegovina, Tahtali Sokak 17, 71000 Sarajevo, Bosnia and Herzegovina; d.maestro@zzjzfbih.ba

8 Department of Environmental Health, Faculty of Health Studies, University of Sarajevo, Stjepana Tomića 1, 71000 Sarajevo, Bosnia and Herzegovina

9 Division for Marine and Environmental Research, Ruder Bošković Institute, Bijenička Cesta 54, 10000 Zagreb, Croatia; kada@irb.hr

* Correspondence: arijana.cenov@zzjzpgz.hr (A.C.); drazen.lusic@medri.uniri.hr (D.L.); marin.glad@zzjzpgz.hr (M.G.); Tel.: +385-(0)51-358-755 (A.C.); +385-(0)51-651-111 (D.L.)

+ D.V.L. and N.M. equally contributed to work (both first authors).

Abstract: Considering the fact that water is a basic need of every living being, it is important to ensure its safety. In this work, the data on the presence of the opportunistic pathogen P. aeruginosa in drinking water $(n=4171)$ as well as in pool water $(n=5059)$ in Primorje-Gorski Kotar County in Croatia in the five-year period (2016-2020) were analysed. In addition, the national criteria were compared with those of neighboring countries and worldwide. The proportion of $P$. aeruginosapositive samples was similar for drinking water (3.9\%) and pool water (4.6\%). The prevalence of this bacterium was most pronounced in the warmer season. P. aeruginosa-positive drinking water samples were mostly collected during building commissioning, while pool samples were from entertainment and spa/hydromassage pools. Outdoor pools showed a higher percentage of positive samples than indoor pools, as well as the pools filled with freshwater rather than seawater. The highest $P$. aeruginosa load was found in rehabilitation pools. Croatia, Serbia and Montenegro are countries that have included P. aeruginosa in their national regulations as an indicator of the safety of water for human consumption as well as for bottled water, while Slovenia and Bosnia and Herzegovina have limited this requirement to bottled water only. In the case of swimming pool water, this parameter is mandatory in all countries considered in this study.

Keywords: water safety; drinking water; swimming pool water; microbiological parameters; water quality criteria

\section{Introduction}

Genus Pseudomonas belongs to the family Pseudomonadaceae, of which Pseudomas aeruginosa is the most important. P. aeruginosa is a Gram-negative bacterium that is ubiquitous in the aquatic environment in which it can multiply, but also on the surface of suitable 
organic materials and filters that come into contact with water. It is capable of colonizing various niches in the aquatic environment as well as numerous moist sites in the soil [1]. Furthermore, it can survive for months in a moist environment. This is due to its good adaptation to environmental conditions, ability to survive in a wide range of temperatures and minimal nutrient requirements. Thermoresistance, i.e., temperature tolerance in the range of 4 to $42{ }^{\circ} \mathrm{C}$, allows its survival in various water media: drinking water, hot baths, distilled water, running and standing water, pool water, etc. [2].

Since water is a basic need of every living being, it is important to ensure its safety, whether it is water intended for human consumption or for recreation and rehabilitation. Humans consume large quantities of water for water supply, agriculture, industry, energy production and pharmaceutical and recreational purposes. Protecting the quality of drinking water is certainly a priority over water used for other purposes (agriculture, industry, electricity). However, due to the impaired quality and strong promotion of the use of packaged water, drinking tap water is a common way of consumption used in fewer and fewer countries. A revised EU Directive on the quality of water intended for human consumption, published in December 2020 [3], emphasizes better access to tap water in public places for all consumers, which should reduce the use of bottled water and reduce the amount of plastic waste. However, the presence of large numbers of $P$. aeruginosa in drinking water, especially in bottled water, affects the sensory properties of water, such as taste, odor and turbidity [4]. Although such water is not considered dangerous to a healthy population, immunocompromised individuals (children, elderly, patients) may experience health problems. The presence of $P$. aeruginosa in water also serves as a good indicator of the condition or cleanliness of the distribution system. This is very important for the internal network in the facilities (part of the water supply network from the official place of water delivery, to the water meter and to the consumer's tap), which is not as controlled as much as an external water supply network.

The use of safe water offers many benefits that contribute to positive health effects in an accelerated lifestyle and help us maintain a physical fitness. Therefore, swimming pools have become an indispensable part of the offer of modern tourism, which are used not only for recreational purposes but also for health and rehabilitation (pools in health centers where a hydrotherapy program is carried out after various injuries). Thus, wellness tourism is a growing branch, both globally and in the Republic of Croatia. Nevertheless, exposure to chemical or microbiological contamination is possible during the pool's use. Ensuring and controlling the good quality of pool water minimizes the harmful impact on human health and is a significant public health issue. The pool water and the surrounding areas represent an important reservoir of $P$. aeruginosa, in which the wet skin of the user and the favorable water temperature provide the ideal conditions for reproduction of this bacterium. This is especially true for pools filled with hot water, which are used for recreational or health purposes. Due to their complexity, pool pipelines are difficult to clean, representing an important factor for contamination by P. aeruginosa [5] due to their being a high incidence of this microorganism inside the pipes. The detection of $P$. aeruginosa in pool water samples serves as an indicator of the inadequate or poor management of pools and surrounding areas, as well as non-compliance with the rules of conduct by pool users.

$P$. aeruginosa has the ability to form a biofilm to which the water supply system is extremely sensitive. It can colonize new areas or join to existing ones. Biofilms are defined as thin, complex structures composed of microorganisms and a gelatinous matrix consisting of extracellular polymeric substances (EPS) secreted by the microorganisms present. They are considered as the main sources of microorganisms in the water supply network [6]. Their growth and development are influenced by numerous factors such as the choice of pipe material, availability of nutrients, variations in water flow, temperature, $\mathrm{pH}$, water hardness, presence of disinfectants, etc. [4,6]. Biofilm has a protective role for bacteria as it facilitates their survival and increases their resistance to disinfectants and antibiotics. The adaptability of $P$. aeruginosa to different environments and its ability to thrive under conditions prevailing in biofilms are related to its ability to use nitrate as an 
electron acceptor instead of oxygen. When oxygen, nitrate and nitrite are not available, $P$. aeruginosa can grow or survive by fermentation of arginine or pyruvate [7]. The formation of biofilms not only affects water quality but also poses a threat to humans as it can release pathogenic bacteria such as Salmonella typhimurium, Escherichia coli and Cryptosporidium parvum. Once formed, biofilms are difficult to remove from artificial aqueous systems, either with biodispersants (biofilm-degrading chemicals) or physically before disinfection [4]. Flushing the pipes with compressed air and water is recommended as one of the more successful methods [6].

P. aeruginosa is an opportunistic pathogen that causes disease primarily in immunocompromised individuals. In the general population, in people without predisposing factors, it rarely causes more severe disease $[8,9]$. Populations at risk include infants, patients with neutropenia, burns or AIDS, patients using invasive devices (e.g., catheters, endotracheal tubes, ventilators), diabetics with untreated wounds, patients with underlying lung disease such as bronchiectasis or cystic fibrosis, and individuals with physical eye damage $[1,8]$. In the population of hot tub users, it is the leading cause of folliculitis. In individuals who spend prolonged periods of time in water, it causes inflammation of the outer ear or "swim ear". In patients with cystic fibrosis [5], it is the major cause of morbidity and mortality as these patients are more likely to become colonized with $P$. aeruginosa, leading to severe progressive lung infections [9].

Antimicrobial resistance is a major challenge in the treatment of P. aeruginosa infections as it is one of the most common causes of nosocomial infections caused by Gram-negative bacteria [5]. Antibiotic-resistant $P$. aeruginosa infections often lead to increased treatment costs, prolonged hospital stays and higher morbidity and mortality. The main route of infection is the exposure of sensitive tissues (especially wounds and mucous membranes) to contaminated water or contaminated surgical instruments [9]. P. aeruginosa can be transmitted between patients, through the hands of medical personnel, by direct contact with tap water or from a reservoir [10]. Monitoring the resistant strains of $P$. aeruginosa may be important in preventing potential epidemics that may break out in the future as this bacterium tends to multiply rapidly when chlorine concentrations fall below recommended levels [5]. Although water baths, showers, swimming pools and similar locations are significant sources of Pseudomonas infections, in most cases, infections still occur in health care facilities, intensive care units, nursing homes and other facilities where immunocompromised individuals reside. In these settings, monitoring the presence of P. aeruginosa is of utmost importance.

The aim of this study was to investigate the presence and number of microbiological indicators of $P$. aeruginosa in drinking water and swimming pool water in Croatia, particularly in Primorje-Gorski Kotar County, over a five-year period (2016-2020). Correlation analysis of $P$. aeruginosa indicators and other studied physico-chemical and microbiological indicators was performed. In addition, national legislation regarding the use of P. aeruginosa as a routine indicator of drinking and pool water quality was compared with neighboring countries and worldwide.

\section{Materials and Methods}

A total of 9230 samples were analyzed during the study. 4171 drinking water samples and 5059 pool water samples from 260 pools were analyzed in Primorje-Gorski Kotar County, Croatia. All samples were collected and processed in the period from 2016 to 2020. For the purpose of physico-chemical analysis, water samples were filled into chemically clean glass bottles and for the purpose of microbiological analysis, the water samples were filled into chemically clean and sterile glass bottles with the addition of sodium thiosulfate (Sigma-Aldrich, Darmstadt, Germany) to neutralize any chlorine in the samples. Samples were delivered to the laboratory in light-protected transport refrigerators. If it was not possible to perform a laboratory test immediately, the samples were stored at $+4{ }^{\circ} \mathrm{C}$ for a maximum of $24 \mathrm{~h}$. 
When sampling the tap water, any attachments on the faucet were removed from the tap and the water was allowed to flow for some time before sampling. When sampling the pool water, the sampling point was at least $30 \mathrm{~cm}$ from the edge of the pool and about $30 \mathrm{~cm}$ below the water surface. Depending on the size and shape of the pool, samples were taken from different pool locations to ensure sampling representativeness. Sampling was carried out once a month for indoor pools and twice a month for outdoor pools.

The parameter of $P$. aeruginosa was tested using the membrane filtration technique according to the standard method ISO 16266:2008 [11]. A volume of $100 \mathrm{~mL}$ of the water sample (or appropriate sample dilution) was filtered through a mixed cellulose ester membrane with a pore size of $0.45 \mu \mathrm{m}$ and a diameter of $47 \mathrm{~mm}$ (Pall Corporation, Ann Arbor, MI, USA). The membrane was transferred to Pseudomonas agar base supplemented with glycerol and CN supplement (Biolife Italiana S.r.l., Milan, Italy). The plates were incubated at $(36 \pm 2)^{\circ} \mathrm{C}$ for $24-48 \mathrm{~h}$. All green/blue colonies were confirmed as $P$. aeruginosa. Colonies that were fluorescent under the Wood lamp (SPECTROLINE ${ }^{\circledR}$, New York, NY, USA) and reddish-brown colonies that were not fluorescent, were counted as suspect. All suspect colonies were confirmed using the acetamide broth test for the ability of $P$. aeruginosa to produce ammonia from acetamide (Biolife Italiana S.r.1., Milan, Italy), the oxidase test (Biolife Italiana S.r.l., Milan, Italy) and King's B medium, which enhances the production of fluorescein (Biolife Italiana S.r.l., Milan, Italy).

In addition to the microbiological parameter P. aeruginosa, other microbiological parameters were also tested in drinking water samples and pool samples. They were coliform bacteria and E. coli (ISO 9308-1:2014/AMD 1:2016) [12], S. aureus (Standard methods 23rd. Ed 2017; 9213 B) [13], L. pneumophila (ISO 11731:2017) [14], Heterotrophic Plate Count at $37{ }^{\circ} \mathrm{C} / 48 \mathrm{~h}$ and $22{ }^{\circ} \mathrm{C} / 72 \mathrm{~h}\left(\mathrm{HPC} / 37^{\circ} \mathrm{C}, \mathrm{HPC} / 22{ }^{\circ} \mathrm{C}\right.$; ISO 6222:1999) [15]. The following physico-chemical parameters were tested: water temperature (Standard methods 23rd. Ed 2017; 2550 B) [16], turbidity (ISO 7027-1:2016) [17], electrical conductivity (ISO 7888:1985) [18], free chlorine concentration (ISO 7393-2:2018) [19], pH (ISO 10523:2008) [20], permanganate index $\left(\mathrm{KMnO}_{4}\right.$ consumption; ISO 10523:2008) [20], trihalomethanes (ISO 10301:1997) [21], ammonia (ISO 7150-1:1984) [22], chlorides (ISO 10301:1997 and ISO 9297:1989 modified) [21,23] and nitrates (ISO 10301:1997) [24].

The results are presented using descriptive statistics: relative frequency, arithmetic mean and median, standard deviation (SD), interquartile range (IQR) and data range as measures of data dispersion, as well as graphically. The normality of data distribution was tested using the Kolmogorov-Smirnov test. Since data distribution did not follow the Gaussian curve, Spearman's correlation coefficient was performed using TIBCO Statistica v. 13.5.0 software package (TIBCO Software Inc., Palo Alto, CA, USA), at a significance level of $p<0.05$.

\section{Results and Discussion}

\subsection{Drinking Water}

\subsubsection{Occurrence of P. aeruginosa in Drinking Water}

During the five-year period (2016-2020), 4171 drinking water samples were analyzed for the indicator P. aeruginosa in the territory of Primorje-Gorski Kotar County, Croatia. The trend in the number of analyzed samples in the observed period is decreasing. The largest number of samples tested for the presence of $P$. aeruginosa in the observed period was in 2016 (1094) with the lowest proportion of positive samples (1.1\%). On the other hand, 2018 had the lowest number of samples tested (685) and the highest proportion of $P$. aeruginosa-positive samples (6.6\%) (Figure 1a). During the observed period, the proportion of positive samples had increased. By month, the greatest proportion of positive samples was recorded in the warmer part of the year, as higher temperatures favored the growth of this bacterium [2]. The largest proportions of positive samples were recorded in August (15.4\%), September (10.7\%) and October (10.6\%) (Figure 1b). 

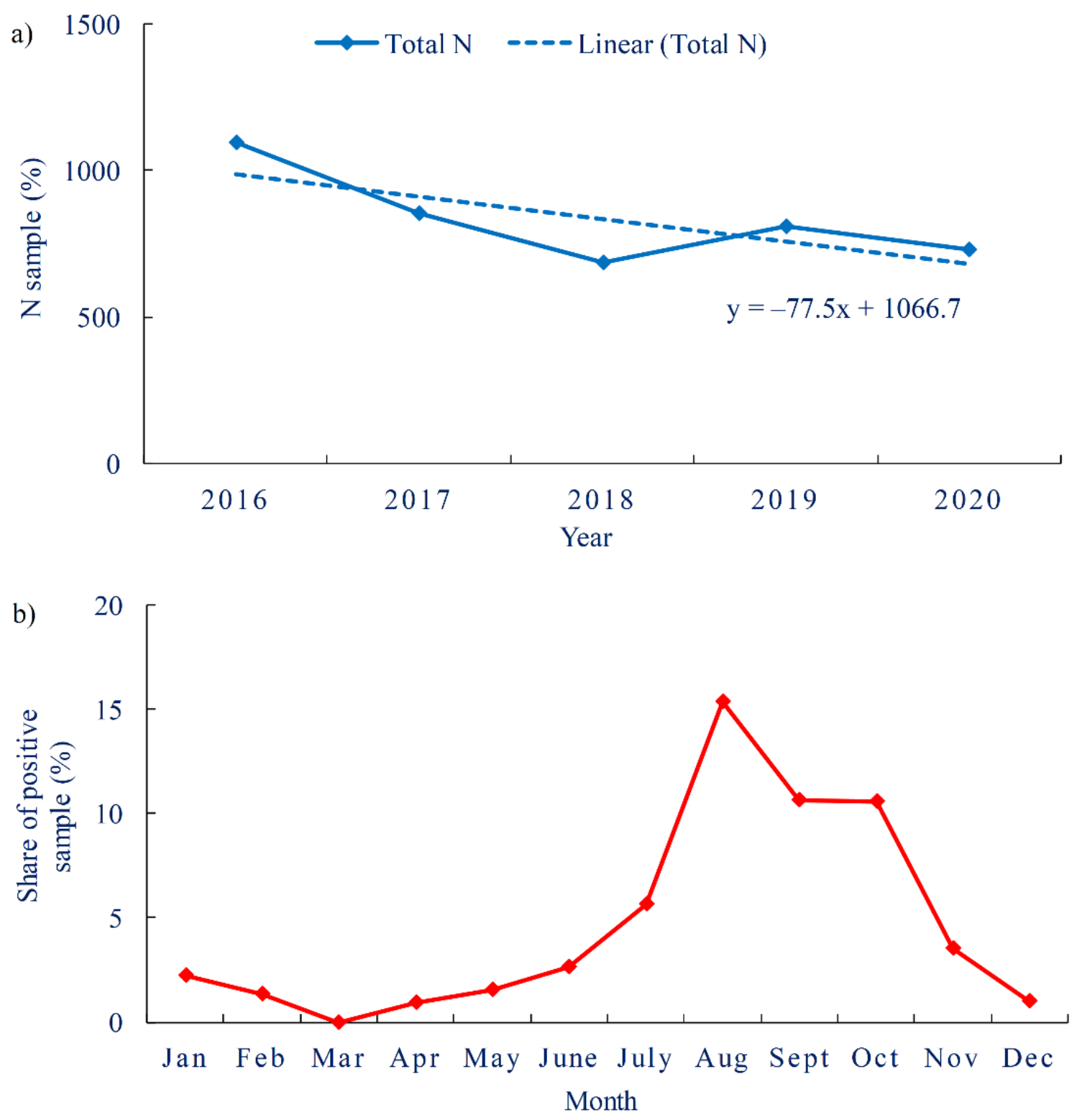

Figure 1. Water samples intended for human consumption (a). Total number of tested samples per year with red-marked share of $P$. aeruginosa-positive samples (b). Share of $P$. aeruginosa-positive water samples by months.

Of the total number of samples tested, $3.9 \%$ were positive for the presence of $P$. aeruginosa (162), in a concentration range of 1-2000 CFU/100 mL, with more than half of the samples having a concentration $<5 \mathrm{CFU} / 100 \mathrm{~mL}$. The proportion of positive samples was generally in line with those found in other studies, which were generally below $2 \%$, with the most commonly detected concentration of 3-4 CFU/100 mL [25]. Most samples were taken when facilities were commissioned (newly constructed and renovated buildings), with a proportion of positive samples of 3.8\% (155/4116, Figure 2a). In the construction of a new water supply network, the proportion of positive samples was significantly higher $(12.7 \% ; 7 / 55)$, which is closer to the values obtained in 2016 in a study conducted in Brazil in the São Paulo State, where the proportion of P. aeruginosa-positive samples in the municipal public water supply was $7.6 \%$ [26]. In addition, the concentration of $P$. aeruginosa in the new water supply network was higher (median 9 CFU / $100 \mathrm{~mL}$, IQR 9-26 CFU / $100 \mathrm{~mL}$ ) than in the samples taken during the commissioning of the building (median 4 CFU /100 mL, IQR 4-21 CFU/100 mL, Figure 2b). 

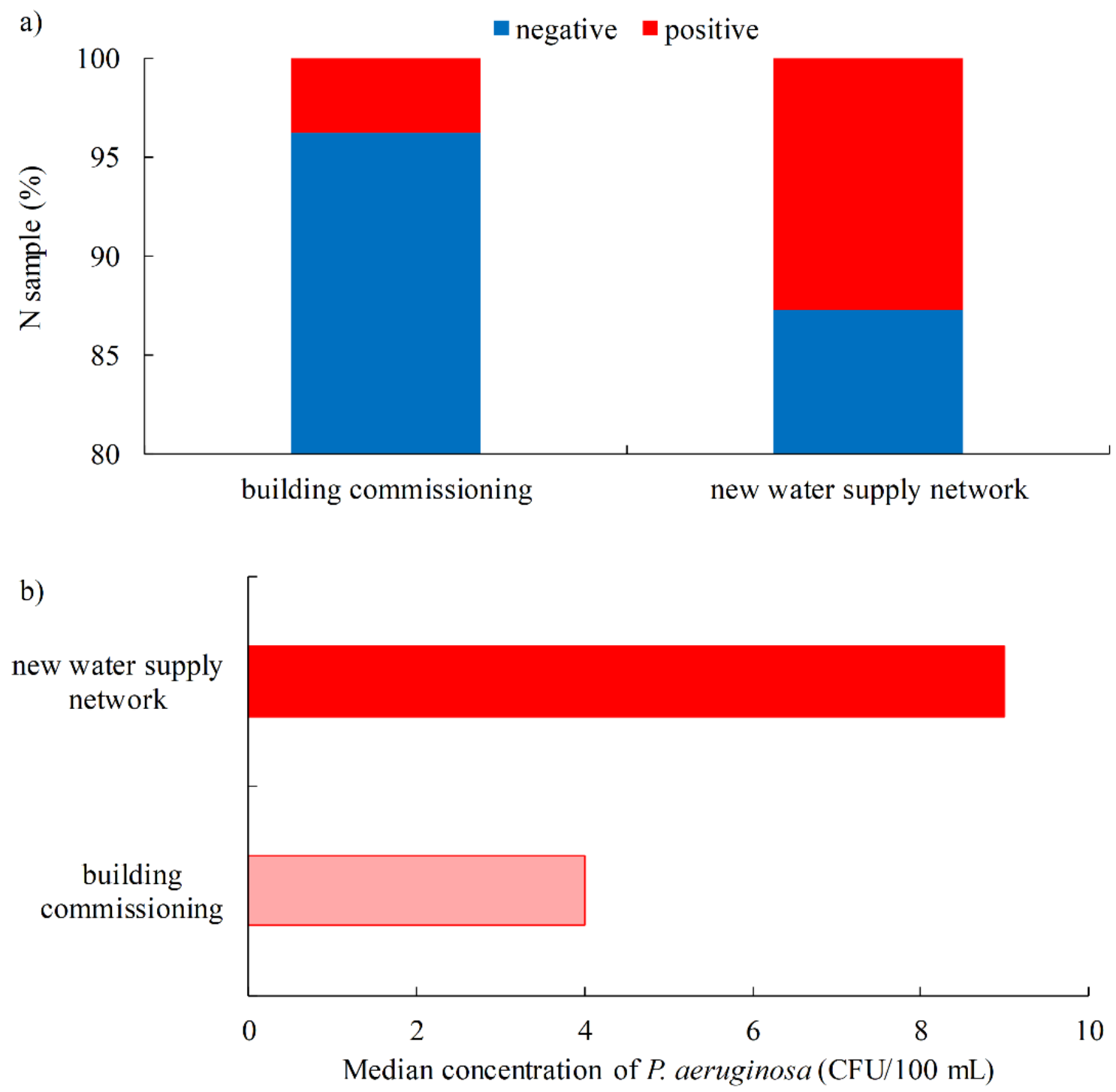

Figure 2. Water samples intended for human consumption, according to the type of sampling points (a). The share of $P$. aeruginosa-positive samples; (b). Median concentration of $P$. aeruginosa.

The load of $P$. aeruginosa in water can be divided into four categories: low, medium, high and very high (Figure 3). If the concentration of P. aeruginosa is $<10 \mathrm{CFU} / 100 \mathrm{~mL}$, the samples are considered to have a low P. aeruginosa load and, in these cases, a risk assessment should be carried out when using such water. Samples with P. aeruginosa concentration values in the range of 10-100 CFU / $100 \mathrm{~mL}$ (medium load), 100-1000 CFU / $100 \mathrm{~mL}$ (high load) and $\geq 1000 \mathrm{CFU} / 100 \mathrm{~mL}$ (very high load) are not satisfactory and further sampling is required (36). Among the drinking water samples tested during the study period, the smallest proportion of positive samples went into the very high (3.1\%) and high load (5.6\%) categories. The medium load category accounted for $26.5 \%$, while the low load category accounted for the largest proportion of positive samples (64.8\%).

Of the total number of $P$. aeruginosa-positive samples, only $13.6 \%(22 / 162)$ showed the presence of coliform bacteria and $1.2 \%(2 / 162)$ that of $E$. coli. In a study conducted in Mexico during an epidemic of gastroenteritis in 28 children aged 1-5 years, five were found to have primary infection by E. coli and secondary infection by P. aeruginosa. Drinking water has been shown to be a possible route of disease transmission. Due to problems with the continuity of the water supply, it is a common practice in these areas to store water in individual household tanks before use. This shows that coliform bacteria/E. coli 
cannot be considered as a reliable and sole indicator of drinking water safety [27]. Bacterial indicators (coliforms, E. coli, enterococci) do not always successfully reflect water quality in a situation where the water meets established bacterial standards but contains bacterial pathogens, viruses or parasites [28,29].

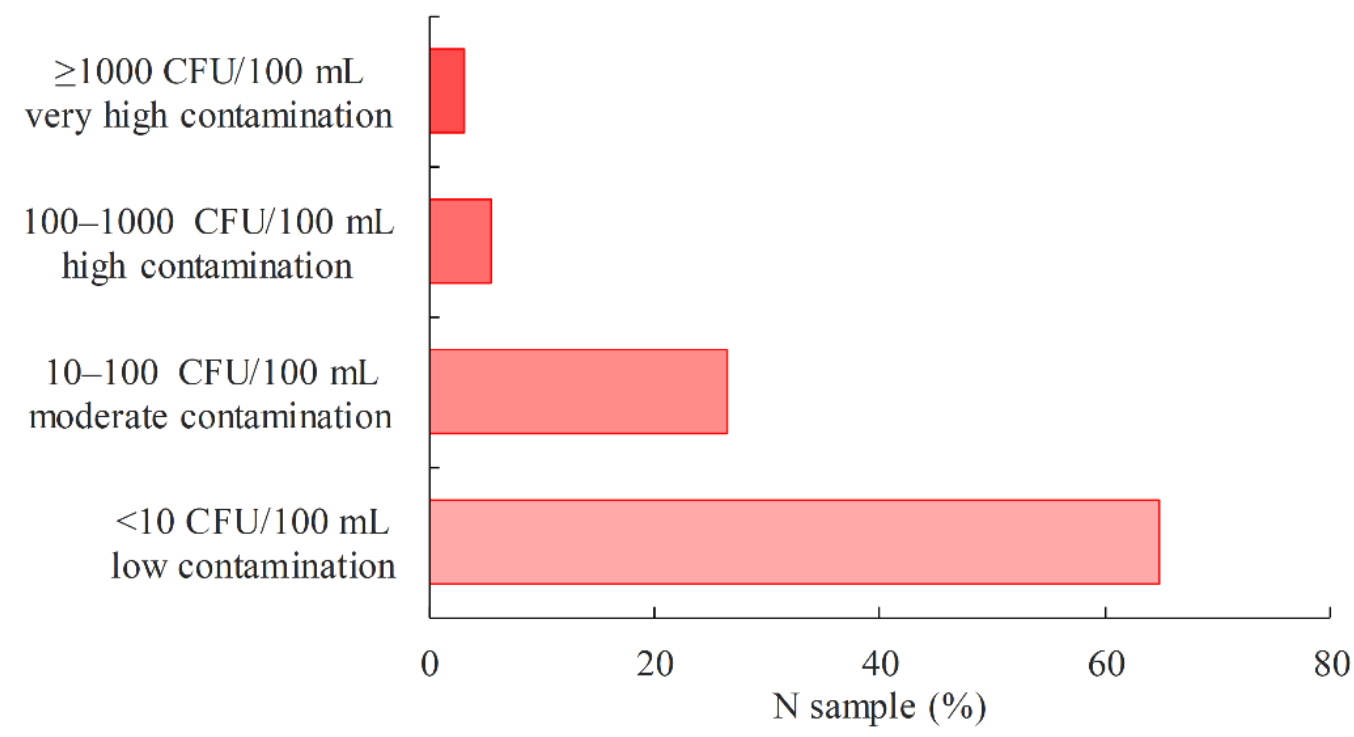

Figure 3. Proportion of P. aeruginosa-positive drinking water samples in relation to the P. aeruginosa load.

P. aeruginosa was positively correlated with all microbiological parameters, while, amid the physico-chemical parameters, only turbidity and ammonia were not significantly associated with $P$. aeruginosa. The strongest positive correlation was observed between $P$. aeruginosa and $\mathrm{HPC} / 37^{\circ} \mathrm{C}(\mathrm{rs}=0.21), \mathrm{HPC} / 22{ }^{\circ} \mathrm{C}(\mathrm{rs}=0.20)$, coliform bacteria $(\mathrm{rs}=0.16)$ and water temperature ( $\mathrm{rs}=0.15)$. The strongest negative correlation was found between $P$. aeruginosa and free residual chlorine ( $\mathrm{rs}=-0.07)$ and nitrate ( $\mathrm{rs}=-0.06)$. The standard HPC test is thought to detect most heterotrophic bacteria in water that are not pathogenic to humans. However, particular genera such as Acinetobacter, Pseudomonas, Xanthomonas, Moraxella, Aeromonas and Klebsiella, which were also detected by this test, included certain opportunistic species [25,30].

In all samples, where the presence of P. aeruginosa was detected, the measured residual chlorine concentration was within the range of $0.2-0.5 \mathrm{mg} / \mathrm{L}$. In $98 \%$ of the samples, the residual chlorine concentration was within the range of $0.2-0.25 \mathrm{mg} / \mathrm{L}$ and only $2 \%$ of the samples were ranging between 0.25 and $0.5 \mathrm{mg} / \mathrm{L}$. As a result, all samples met the Croatian national criterion for the residual chlorine concentration, which only set the upper limit of $0.5 \mathrm{mg} / \mathrm{L}$. The obtained results were consistent with the results of a study conducted in Brazil in 2016 [26], with the difference that the Brazilian regulations also set the lower limit for residual chlorine concentration of $0.2 \mathrm{mg} / \mathrm{L}$. This suggests that $P$. aeruginosa is resilient to the normal chlorine concentrations used by conventional water treatment.

$P$. aeruginosa is sensitive to the action of a disinfectant. However, disinfection is aggravated by the strong affinity of this bacterium for biofilm formation, which estimates to account for up to $95 \%$ of all microorganisms present in the water supply system $[10,27,30]$. This poses a problem in determining the presence of microorganisms, since routine programs of drinking water monitoring include only bulk water. An additional problem in determining the presence and numbers of $P$. aeruginosa by conventional cultivation methods is the viable but non-culturable state (VBNC state) in which this bacterium is usually harbored in biofilms [31]. Although standard water treatment removes most of the microorganisms, there are a number of areas in large piping systems where biofilms can form due to the complexity of these systems. Improperly used fittings, non-metallic pipe materials, dead legs and blind ends, places where water often stagnates or where organic material accumulates, all make suitable conditions for biofilm development. $P$. 
aeruginosa is a bacterium that has the oxidative metabolism of carbohydrates. Therefore, it proliferates the most in terminal outlets of water supply systems where the greatest amount of oxygen is present [32,33]. There, under favorable conditions, P. aeruginosa multiplies rapidly and forms a biofilm that binds to the surface of the distribution network material with an extracellular polymeric substance (EPS) [34]. Once biofilm has formed in the water supply network, its removal presents a major challenge. Prior to the water disinfection process, the biofilm must be physically removed and/or biodispersants (chemical solvents) must be used.

\subsubsection{Drinking Water Legislation}

Croatian regulations instituting the criteria for the safety of drinking water (OG $125 / 2017,39 / 2020)$ states that $P$. aeruginosa is routinely determined in water samples taken at the point of consumption in public health facilities: hospitals and other health care facilities, nursing homes and other public facilities housing the elderly, and for the purposes of the commissioning of the buildings [35].

While the above regulation defines the parameter P. aeruginosa as an "indicator parameter" for water intended for human consumption (which does not necessarily represent a health risk), it represents the safety parameter for bottled or packaged water, to be determined in a $250 \mathrm{~mL}$ sample. In both cases, the presence of P. aeruginosa must not be detected in the quantity of water tested. Therefore, the Republic of Croatia, through its national legislation, like some other countries in Europe [36,37], has limited the testing of $P$. aeruginosa in drinking water mainly to vulnerable populations.

Regulation OG 24/2012 on the hygienic quality of drinking water is a regulation that specifies in more detail the requirements for the safety of drinking water in Montenegro. Among other indicators, it lists P. aeruginosa, the presence of which must not be detected in $100 \mathrm{~mL}$ of drinking water and in $250 \mathrm{~mL}$ of packaging water [38].

In the Federation of Bosnia and Herzegovina, the Regulation on the Safety of Drinking Water (OG 40/10, 43/10, 30/12 and 62/2017) prescribes the requirements and standards that drinking water must meet [39]. In drinking water, the microbiological indicator of $P$. aeruginosa is not tested, while in packaged water it is mandatory and should not be detected in a sample of $250 \mathrm{~mL}$.

In the Republic of Slovenia, in order to control the quality of drinking water, the rule on drinking water (OG 19/04, 35/04, 26/06, 92/06, 25/09, 74/15, 51/17) is applied, which requires a test for $P$. aeruginosa only for packaged water, where bacteria must not be detected in $250 \mathrm{~mL}$ of water. [40].

In 2017, the World Health Organization (WHO) issued a fourth edition incorporating the first addendum "Guidelines for Drinking-water Quality", recommending the use of water safety plans to ensure the safety of drinking water and to reduce the health impact of water contamination. The WHO guidelines are not mandatory but are a body of knowledge that countries around the world use as a basis for establishing the national criteria. Bacteria, viruses, protozoa and helminths that cause disease through water are described in the chapter of microbiological indicators as well as indicator organisms. Their characteristics, impact on human health, sources of pollution, routes of distribution and the importance of a particular pathogen or indicator from the point of view of drinking water safety are described. Quantitative microbiological criteria for assessing the health safety of drinking water are not stated in this guidance [9].

The U.S. Environmental Protection Agency (US EPA) has published a list of mandatory microbiological indicators that must be tested in water in the National Primary Water Regulations (NPDWRs): Cryptosporidium, Giardia lamblia, HPC, Legionella, total coliforms (including fecal coliforms and E. coli), and enteric viruses [41]. Drinking water quality assessment includes testing for the presence of these parameters, while P. aeruginosa is not on the list of microbial contaminants tested for in routine analyses. In the United States, in 1997, Hardalo, an infectiologist, and Edberg, a microbiologist, conducted a study on the risk of the presence of P. aeruginosa in drinking water. The aim of that study was 
to determine whether the use of the parameter P. aeruginosa, as one of the indicators of drinking water safety is justified. Based on the results of the research, they concluded that, given the ubiquity of this bacterium in the environment, it is not only impractical to try to remove it from food and water but it could also represent danger to people's health. Indeed, the use of higher concentrations of disinfectants leads to the formation of a greater quantity of by-products. These may cause a potentially higher risk to human health than the risk posed by P. aeruginosa to the general population [42].

\subsection{Swimming Pool Water}

\subsubsection{Occurrence of P. aeruginosa in Swimming Pool Water}

Over a five-year period (2016-2020) in the study area a total of 5059 samples of pool water were analyzed for the parameter P. aeruginosa, with a decreasing trend. Of the samples tested, 233 (4.6\%) were positive for P. aeruginosa. The results of $P$. aeruginosa monitoring in swimming pool water were very different in the different studies. For example, the percentage of positive samples for P. aeruginosa was $0 \%$ and $63.6 \%$ in Iran $[43,44], 3.3 \%$ and $21.7 \%$ in Egypt [45,46], 19.1\% in Italy [47], 38\% in Northern Ireland [48] and 69.2\% in China [49].

Looking at the yearly distribution of the number of pool water samples tested for $P$. aeruginosa (Figure 4a), the largest number of samples tested was recorded in 2018 (1263). The proportion of samples in which $P$. aeruginosa was detected during the studied period ranged from 2.1\% (2020) to 9.4\% (2019) (Figure 4b). The differences in the proportions of $P$. aeruginosa-positive samples may be related to variations in the number of tourists who visited Croatia in a given season. Namely, according to the Central Statistical Office of the Republic of Croatia, in 2019 the highest number of tourist arrivals in commercial accommodation was recorded in Primorje-Gorski Kotar County $(2,966,489)$, while in the 2020 season it was the lowest $(1,323,560), 55 \%$ less than in the record year 2019 [50]. The reason for the sharp decrease in the number of tourists in the 2020 season was certainly the circumstances related to the COVID-19 pandemic. According to the monthly distribution, the largest proportion of P. aeruginosa-positive samples was found in October (6.6\%).

The highest percentage of $P$. aeruginosa-positive samples was found in entertainment pools $(13.8 \%)$, followed by spa/hydromassage pools $(4.7 \%)$, children and recreational pools $(3.9 \%)$, rehabilitation pools $(2.1 \%)$ and, finally, sports pools with a percentage of $1.2 \%$ (Figure 5a). However, when looking at the level of P. aeruginosa contamination, a somewhat different picture emerges. The highest concentrations of $P$. aeruginosa were found in rehabilitation pools (median 20 CFU /100 mL, IQR 20-130 CFU/100 mL), followed by spa/hydromassage pools (median 10 CFU/100 mL, IQR 10-553 CFU/100 mL) (Figure 5b). The reasons for the high percentage of positive results of $P$. aeruginosa in entertainment pools may be attributed to the complexity of the structure of such pools, which increases the possibility of biofilm formation, making maintenance much more difficult. As for the highly contaminated rehabilitation pools, there are many reasons for that. Rehabilitation pools are mostly used by elderly patients, and the number of pool users is usually high because these pools have a limited operating time [51]. The high temperatures and ventilation in spa/hydromassage pools lead to the increased sweating and desquamation of the users' skin. In addition to the high temperatures, which are usually above $32{ }^{\circ} \mathrm{C}$, these pools are characterized by a lower volume of water per user [5,52]. In this way, the water in whirlpools becomes a medium in which bacteria have access to a greater amount of nutrients, which favors the growth of P. aeruginosa.

A higher proportion of positive samples was confirmed in freshwater $(5.6 \%)$ compared to seawater pools (2.7\%). Moreover, the concentration of $P$. aeruginosa was higher in freshwater pools (mean $283.3 \pm 621.6 \mathrm{CFU} / 100 \mathrm{~mL}$; median $9 \mathrm{CFU} / 100 \mathrm{~mL}$, IQR 9-61 CFU/100 mL) than in seawater pools (mean $65.3 \pm 309.2 \mathrm{CFU} / 100 \mathrm{~mL}$; median 5 CFU / $100 \mathrm{~mL}$, IQR 5-10 CFU/100 mL). These results are consistent with previous studies conducted in Croatia in 2017, which included 1128 pools (85\% freshwater and 15\% seawater). P. aeruginosa was detected more frequently in freshwater pools $(2.8 \%)$ than in 
seawater pools (1.4\%) [53]. It was also found that the percentage of P. aeruginosa-positive samples was slightly higher in outdoor pools than in indoor pools $(4.9 \%$ and $4.5 \%$, respectively), which was also found in previous studies where the difference between these two types of pools was even greater [44,46,47]. However, the concentration of $P$. aeruginosa was higher in indoor pools (mean $269.6 \pm 607 \mathrm{CFU} / 100 \mathrm{~mL}$; median $8 \mathrm{CFU} / 100 \mathrm{~mL}$, IQR 8-59 CFU/100 mL) than in outdoor pools (mean 172.9 $\pm 549 \mathrm{CFU} / 100 \mathrm{~mL}$; median 5 CFU /100 mL, IQR 5-32 CFU/100 mL), Figure 6a,b.
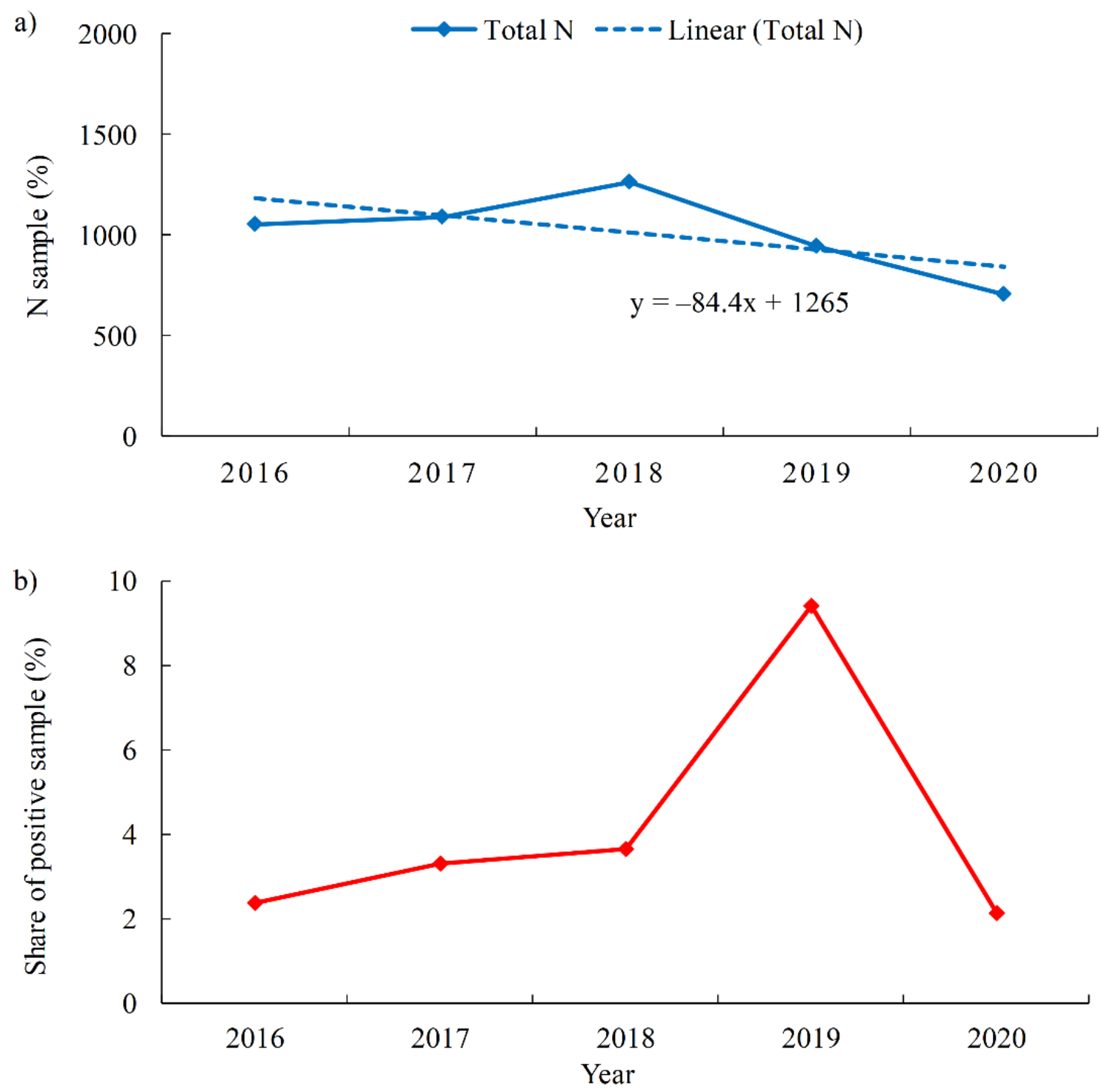

Figure 4. Swimming pool water samples (a). Total number of tested samples per year with red-marked share of $P$. aeruginosapositive samples (b). Proportion of P. aeruginosa-positive swimming pool water samples per year.

The proportion of P. aeruginosa-positive samples depending on the type of disinfectant used is shown in Figure 7a. The highest percentage of positive samples was confirmed when hydrogen peroxide was used as the disinfectant $(32.4 \%)$, which is a significantly higher percentage than the samples from the pool where sodium hypochlorite or chlorine was used as the disinfectant (3.8-4.8\%). Moreover, the highest level of P. aeruginosa contamination was measured when hydrogen peroxide was used (median $11 \mathrm{CFU} / 100 \mathrm{~mL}$, IQR 20-78 CFU / $100 \mathrm{~mL}$ ), while the levels for sodium hypochlorite and chlorine were lower (median 6 CFU/100 mL with IQR 6-27 CFU/100 mL and 6-55 CFU/100 mL, respectively) (Figure $7 \mathrm{~b}$ ). P. aeruginosa has a high catalase activity that degrades hydrogen peroxide to 
oxygen and water, thus increasing the resistance of $P$. aeruginosa to lower concentrations of hydrogen peroxide [54]. Therefore, hydrogen peroxide is not recommended as the sole disinfectant for swimming pool water [55]. According to the data from the United States of America, UV-peroxide systems do not provide an adequate disinfectant effect, and hydrogen peroxide is not approved by the US EPA for use as a disinfectant in recreational waters [56].

a)
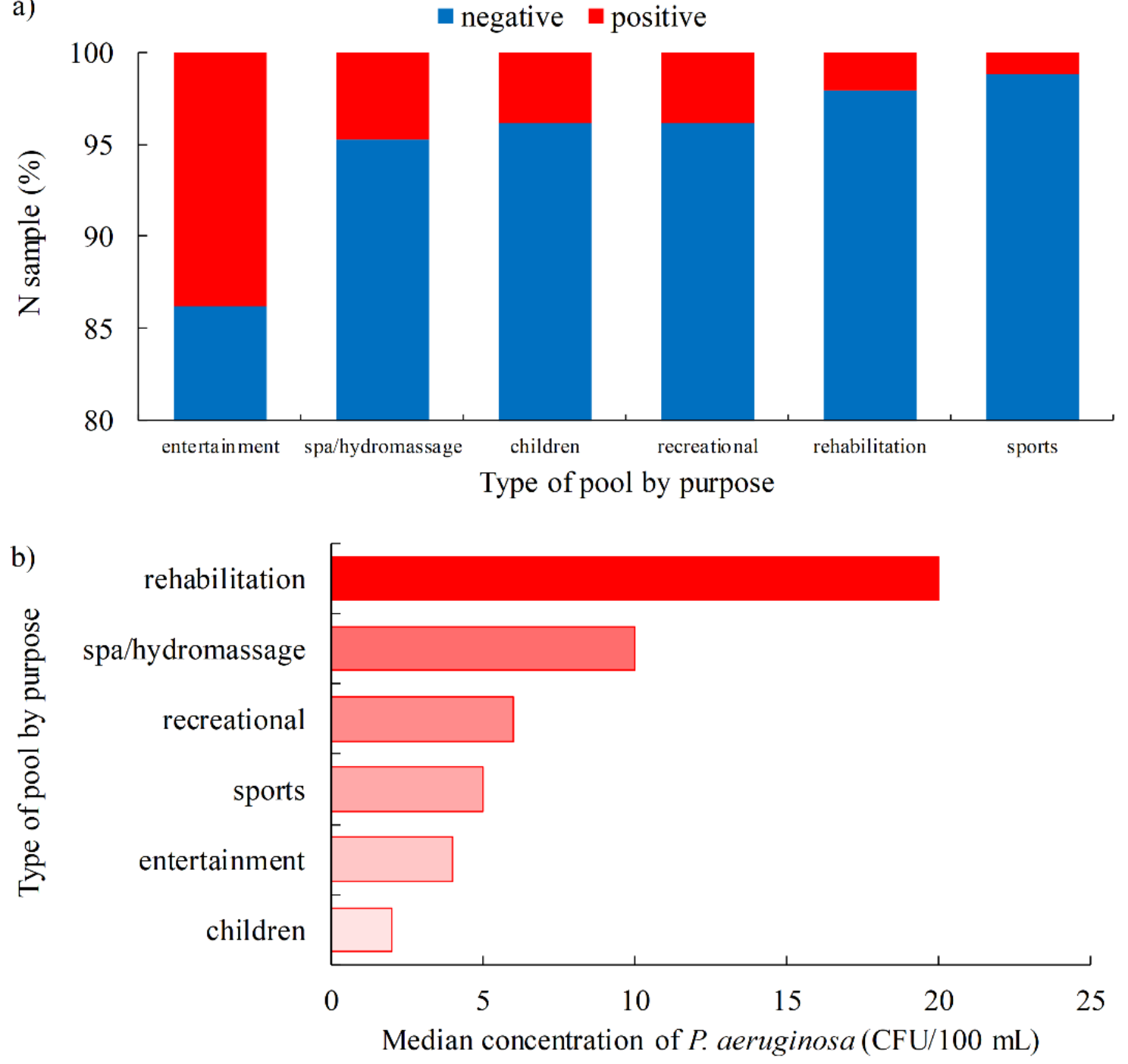

Figure 5. Swimming pool water quality by specific purpose of the pool (a). Proportion of P. aeruginosa-positive samples (b). Median concentration of $P$. aeruginosa.

The proportion of $P$. aeruginosa-positive samples in a given loading category of pool water samples is shown in Figure 8. The lowest proportion (9.4\%) of P. aeruginosa-positive samples belongs to the high load category (100-1000 CFU/100 mL), a slightly higher proportion of $12.0 \%$ belongs to the very high load category ( $\geq 1000 \mathrm{CFU} / 100 \mathrm{~mL}$ ), $24.0 \%$ belongs to the medium load category $(10-100 \mathrm{CFU} / 100 \mathrm{~mL})$ and the highest proportion of $54.5 \%$ belongs to the low load category $(<10 \mathrm{CFU} / 100 \mathrm{~mL})$. It is known from previous studies that $P$. aeruginosa is frequently present in low concentrations in swimming pool water and in the environment $[45,51]$. 


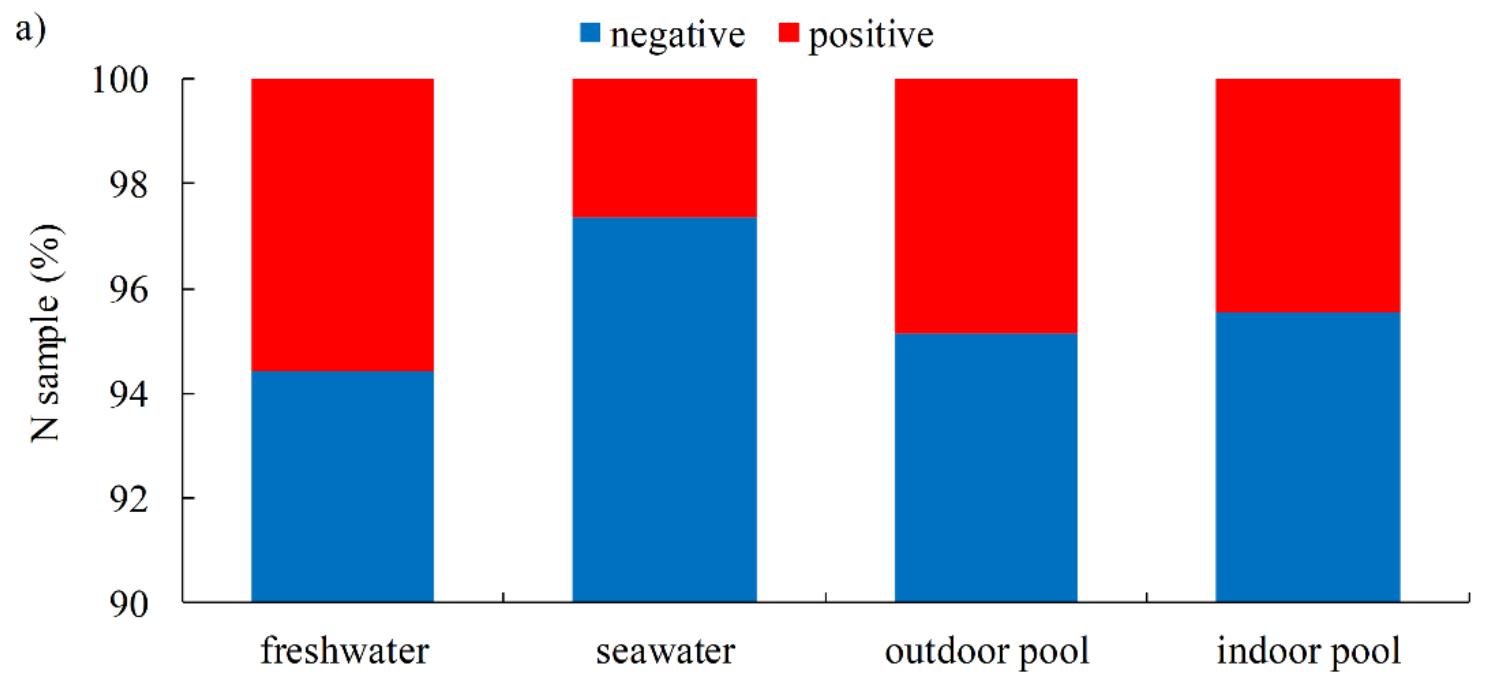

b)

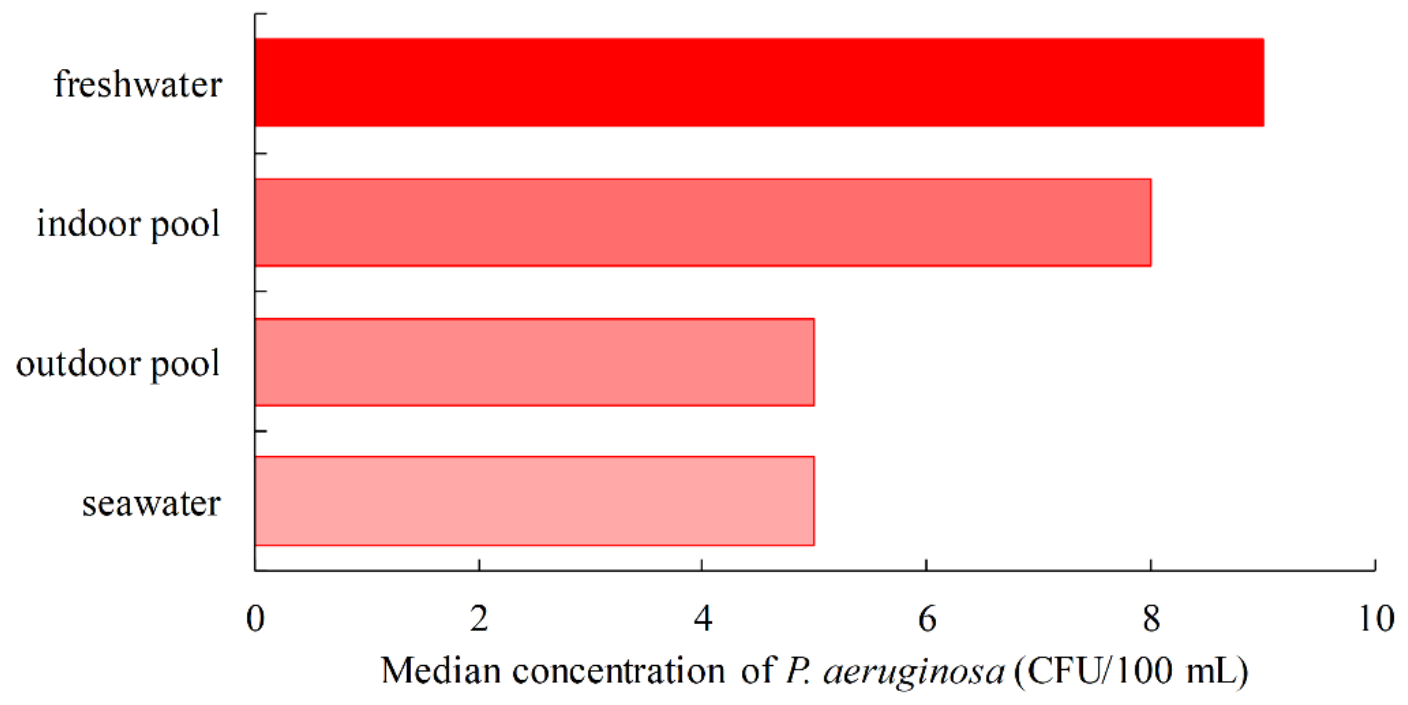

Figure 6. Pool freshwater vs. seawater and outdoor vs. indoor pool water quality (a) Proportion of P. aeruginosa-positive samples and (b) Median concentration of P. aeruginosa.

Correlation analysis showed significant correlation $(p<0.05)$ between P. aeruginosa and all microbiological (except L. pneumophila) and all physico-chemical parameters. The strongest positive correlation was found between P. aeruginosa and E. coli ( $\mathrm{rs}=0.38$ ), $\mathrm{HPC} / 37^{\circ} \mathrm{C}(\mathrm{rs}=0.29)$ and $S$. aureus $(\mathrm{rs}=0.11)$. The results suggest that both fecal and non-fecal human shedding are possible major sources of $P$. aeruginosa contamination of pool water and the environment, as other studies have also noted [44,57]. No significant correlation was found between P. aeruginosa and L. pneumophila, which is not surprising. Actually, it has already been shown that $P$. aeruginosa has an antagonistic effect against L. pneumophila [58], and a significant negative correlation was found between these two bacteria $[59,60]$.

The strongest negative correlation was found between P. aeruginosa and free residual chlorine ( $r s=-0.16$ ), similar to the Egyptian study, $r s=-0.10$. This suggests that maintaining the residual chlorine concentration within the recommended range is one of the ways to control $P$. aeruginosa survival in the pool environment $[45,61]$. However, when analyzing the residual chlorine concentration in the samples in which the presence of $P$. aeruginosa was detected (ranging from 0.02 to $1.74 \mathrm{mg} / \mathrm{L}$ ), it is observed that in more than two-thirds of the samples (72\%) the residual chlorine concentration was less than $0.5 \mathrm{mg} / \mathrm{L}$. According to the results of this study, for the inactivation of $P$. aeruginosa it is necessary 
to apply chlorine in concentrations that will ensure residual chlorine closer to the upper allowed limit (for standard swimming pools of $1 \mathrm{mg} / \mathrm{L}$, while for hot tubs up to $3 \mathrm{mg} / \mathrm{L}$ ).

a)

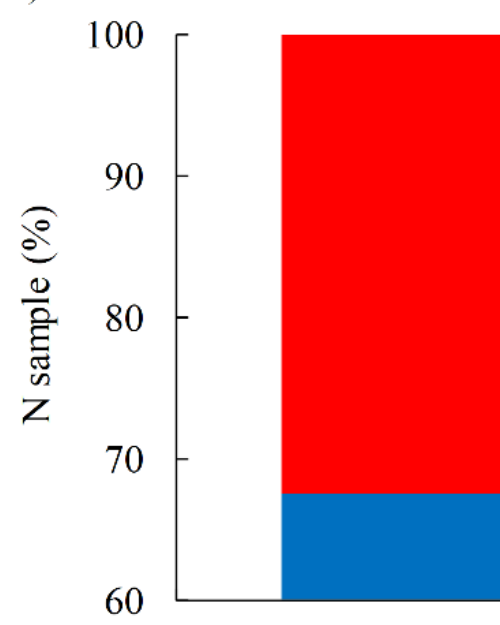

hydrogen peroxide negative $\square$ positive

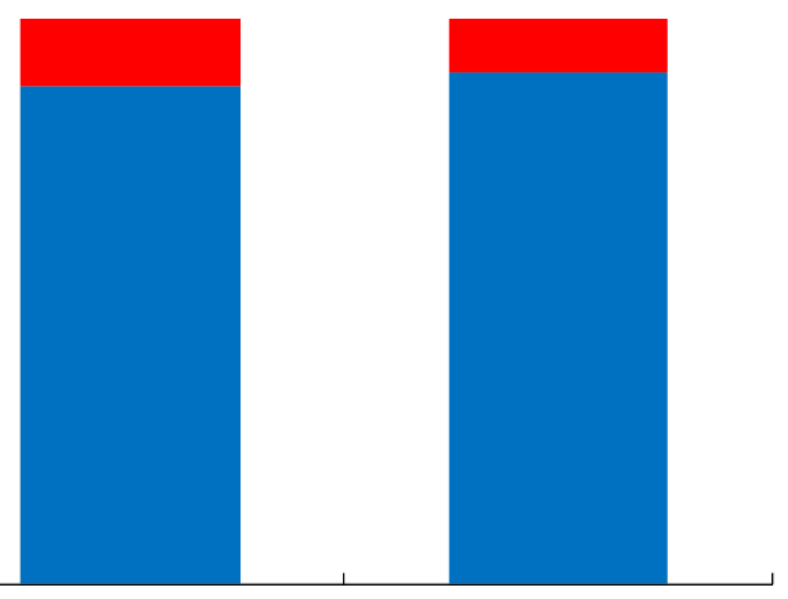

sodium hypochlorite chlorine

b)

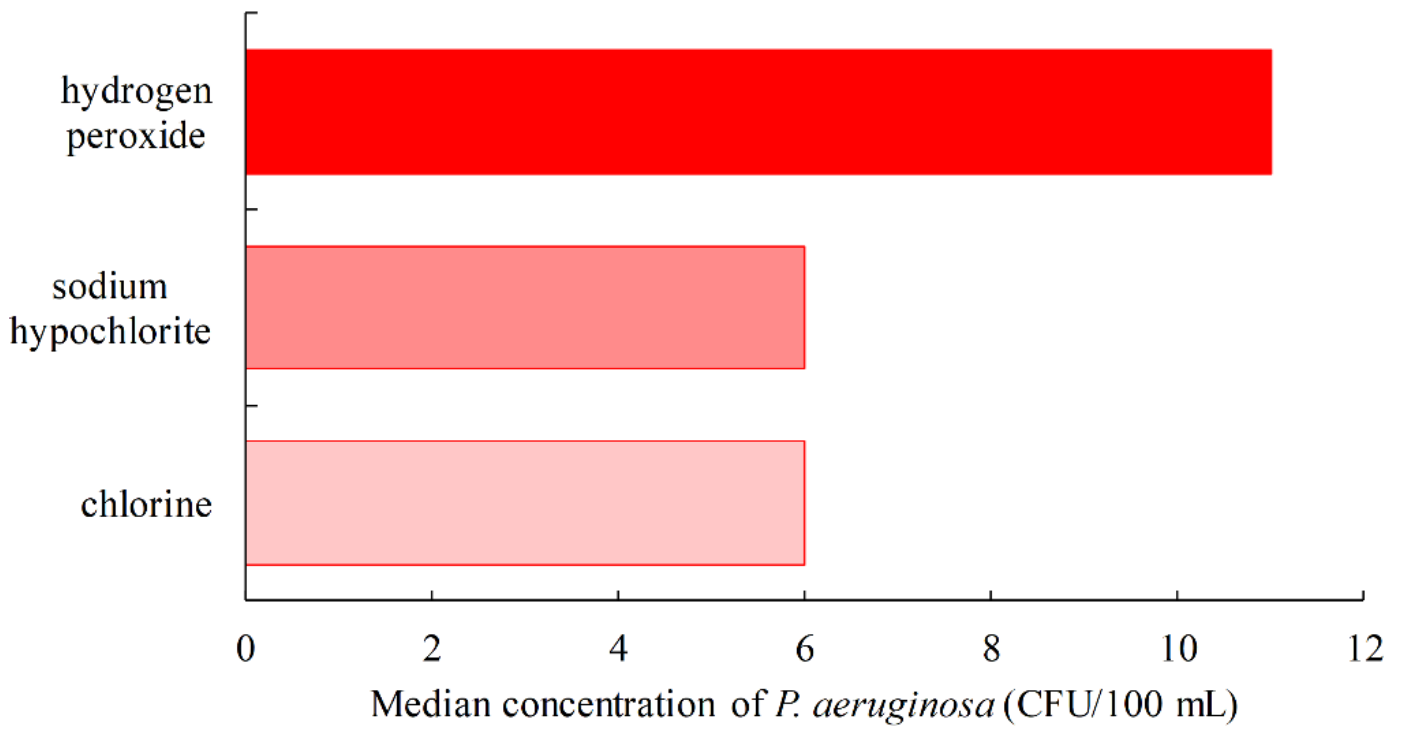

Figure 7. Swimming pool water quality by type of disinfectant (a). Proportion of P. aeruginosa-positive samples (b). Median concentration of $P$. aeruginosa.

\subsubsection{Swimming Pool Water Legislation}

The Croatian Regulation on Health Safety of Swimming Pool Water (OG 59/2020) came into force in 2020 and introduced two categories of swimming pools, namely conventional and biological pools [62]. Conventional pools are standard pools in which the treatment of pool water is conducted by disinfection with residual effect. Biological pools are outdoor pools in which the treatment of pool water is carried out by natural biological processes in the ecosystem of microorganisms, plants and native small animals, which can be supported by technical systems. Biological pools consist of a part for bathing and a part for biological treatment of the water, with a continuous water surface between the two. While in conventional pools the threshold for P. aeruginosa is $0 \mathrm{CFU} / 100 \mathrm{~mL}$, in biological pools it is $10 \mathrm{CFU} / 100 \mathrm{~mL}$. 
Serbia put in force the Regulation (OG 30/2017 and 97/2017), which prescribes the conditions for pool water safety [63]. P. aeruginosa s a mandatory parameter for testing the safety of swimming pool water with a threshold value $<1 \mathrm{CFU} / 100 \mathrm{~mL}$.

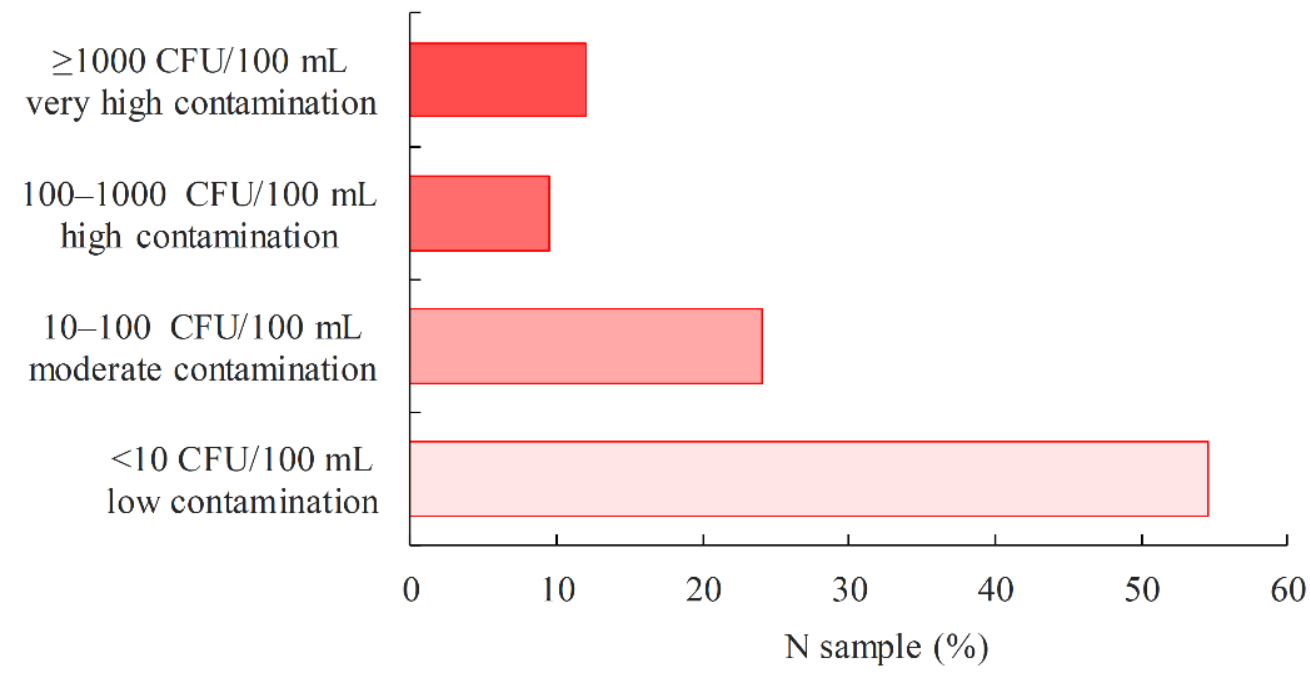

Figure 8. Proportion of $P$. aeruginosa-positive swimming pool water samples in relation to the $P$. aeruginosa load.

Montenegro regulated the quality of swimming pool water by its own Regulation (OG 57/2018). It prescribes the sanitary, technical and hygienic conditions that sports and recreational swimming pools, as well as swimming pools of public health interest, must meet in order to protect the health of the population and to prevent the occurrence of infectious diseases. P. aeruginosa must not be present in $100 \mathrm{~mL}$ of analyzed swimming pool water [64].

In Bosnia and Herzegovina, the Regulation (OG 50/2018) has been in force since 2018, in which $P$. aeruginosa is a mandatory test parameter with a threshold $<1 \mathrm{CFU} / 100 \mathrm{~mL}$ [65].

Slovenia regulates the quality of swimming pool water by the Regulation (OG 59/15, $86 / 15,52 / 18)$. For conventional pools the limit value is $=0 \mathrm{CFU} / 100 \mathrm{~mL}$, and for biological pools it is $10 \mathrm{CFU} / 100 \mathrm{~mL}$ [66].

The WHO Guidelines for safe recreational water environments, swimming pools and similar environments (2006), provide an overview and assessment of the health risks associated with recreational water use. Monitoring is described, as well as factors that influence outcomes (user education, proper pool design and construction, appropriate procedures and successful pool management). Among other physico-chemical and microbiological indicators, the risk of P. aeruginosa is described and good practice examples are given [52].

The American National Standard for Water Quality in Public Pools and Spas (ANSI/APSP112019 ) originated due to the overall poor sanitation of public pools in the decades prior to the first version of the 2009 standard [67]. Its goal was to recommend the minimum guidelines for individual water quality indicators. It was the first national standard to focus primarily on water quality in swimming pools and spas and was based on quality data. It was published by the American National Standards Institute (ANSI) in collaboration with the Association of Pool and Spa Professionals (APSP). It determined the recommended levels for the two major pool water disinfectants: chlorine (2-4 ppm for public pools and 2-5 ppm for spas) and bromine (3-4 ppm for public pools and 4-6 ppm for spas), as well as the optimal $\mathrm{pH}$ of the water (7.2-7.8). It was believed that maintaining the above recommended conditions in swimming pool water would ensure the microbiological safety of the water, while routine testing of microbiological indicators in the water is not required and even considered unnecessary. From a public health perspective, frequent measurement of disinfectant concentration and $\mathrm{pH}$ is a very effective method of controlling water quality. Routine testing of microbiological indicators has several disadvantages: it usually takes 
about $48 \mathrm{~h}$, and the information obtained relates to a period of time that has already passed and is often no longer relevant. In addition, a single result may give a false picture of the condition (false positive or false negative) if the sample was not collected or tested correctly. Even in the case of a correctly collected and analyzed sample, the result may be confusing. For a correct assessment of the quality of the swimming pool water, it is therefore necessary to take a large number of samples over a long period of time, while a single result can be misleading.

\section{Conclusions}

- In total, 3.9\% of drinking water samples were positive for the presence of P. aeruginosa, mainly during the commissioning of buildings or the construction of a new water supply network.

- There is no general agreement on whether it is appropriate to routinely test drinking water in public water systems for the presence of $P$. aeruginosa, as the prevailing opinion is that this bacterium does not pose a health risk to the general population.

- $\quad$ Some countries restrict surveillance for P. aeruginosa by national guidelines to hospitals and other health care facilities, nursing homes and other public facilities housing the elderly. Croatia is one of these countries which, in our opinion, has raised the level of health protection for the most vulnerable population groups, although the standard set does not require the absence of this bacterium in the public water supply, which would be difficult to achieve in real conditions.

- P. aeruginosa was detected more frequently: in outdoor pools (4.9\%) vs. indoor pools (4.5\%); freshwater pools (5.6\%) vs. seawater pools (2.7\%); entertainment pools $(13.8 \%)$ and spa/hydromassage pools $(4.8 \%)$ vs. children $(3.9 \%)$, recreational $(3.9 \%)$, rehabilitation $(2.1 \%)$ and sports pools $(1.2 \%)$; when hydrogen peroxide $(32.4 \%)$ is used as a disinfectant vs. sodium hypochlorite $(4.8 \%)$ and chlorine (3.8\%).

- Unlike water intended for human consumption, the testing of P. aeruginosa in swimming pool water is consistent in all countries covered by this study, where P. aeruginosa is a mandatory parameter for testing of the safety of swimming pool water.

Author Contributions: Conceptualization, N.M., D.V.L. and A.C.; methodology, A.C., M.G. and S.T.; data curation, K.S., D.T.L., S.M.-P., D.M. and N.M.; writing-original draft preparation, K.S., D.T.L., Ž.L., S.M.-P., D.M. and N.M.; writing-review and editing, D.K., D.V.L., S.T. and D.L.; supervision, D.V.L., D.L., D.K. and M.G.; project administration, D.L., A.C. and M.G.; funding acquisition, D.L., Ž.L. and M.G. All authors have read and agreed to the published version of the manuscript.

Funding: This work was supported by the research project: The University of Rijeka "Adaptation to the new EU Bathing Water Directive" (project code: uniri-biomed-18-292).

Institutional Review Board Statement: Not applicable.

Informed Consent Statement: Not applicable.

Data Availability Statement: The data supporting the findings of this study are available within the article.

Acknowledgments: The authors would like to thank the staff of the Teaching Institute of Public Health of Primorje-Gorski Kotar County, Croatia, for their help in sampling and analysis.

Conflicts of Interest: The authors declare no conflict of interest.

\section{References}

1. Bédard, E.; Prévost, M.; Déziel, E. Pseudomonas aeruginosa in premise plumbing of large buildings. Microbiologyopen 2016, 5, 937-956. [CrossRef] [PubMed]

2. Science Direct. Pseudomonas aeruginosa. 2021. Available online: https://www.sciencedirect.com/topics/medicine-anddentistry/pseudomonas-aeruginosa (accessed on 18 October 2021).

3. European Commission. Directive (EU) 2020/2184 of the European Parliament and of the Council of 16 December 2020 on the quality of water intended for human consumption (recast). Off. J. Eur. Union 2020, 435, 1-62.

4. Liu, S.; Gunawan, C.; Barraud, N.; Rice, S.A.; Harry, E.J.; Amal, R. Understanding, monitoring, and controlling biofilm growth in drinking water distribution systems. Environ. Sci. Technol. 2016, 50, 8954-8976. [CrossRef] [PubMed] 
5. Lutz, J.K.; Lee, J. Prevalence and antimicrobial-resistance of Pseudomonas aeruginosa in swimming pools and hot tubs. Int. J. Environ. Res. Public Health 2011, 8, 554-564. [CrossRef]

6. Lehtola, M.J.; Nissinen, T.K.; Miettinen, I.T.; Martikainen, P.J.; Vartiainen, T. Removal of soft deposits from the distribution system improves the drinking water quality. Water Res. 2004, 38, 601-610. [CrossRef]

7. Eschbach, M.; Schreiber, K.; Trunk, K.; Buer, J.; Jahn, D.; Schobert, M. Long-term anaerobic survival of the opportunistic pathogen Pseudomonas aeruginosa via pyruvate fermentation. J. Bacteriol. 2004, 186, 4596-4604. [CrossRef]

8. Diggle, S.P.; Whiteley, M. Microbe Profile: Pseudomonas aeruginosa: Opportunistic pathogen and lab rat. Microbiology 2020, 166, 30-33. [CrossRef]

9. World Health Organization (WHO). Guidelines for Drinking-Water Quality, 4th ed.; Incorporating the 1st Addendum; WHO: Geneva, Switzerland, 2017; Available online: https:/ /www.who.int/publications/i/item/9789241549950 (accessed on 18 November 2021).

10. Penna, V.T.; Martins, S.A.; Mazzola, P.G. Identification of bacteria in drinking and purified water during the monitoring of a typical water purification system. BMC Public Health 2002, 2, 13. [CrossRef]

11. ISO 16266:2008. Detection and Enumeration of Pseudomonas aeruginosa-Method by Membrane Filtration; International Organization for Standardization (ISO): Geneva, Switzerland, 2008.

12. ISO 9308-1:2014/AMD 1:2016. Water Quality-Enumeration of Escherichia coli and Coliform Bacteria-Part 1: Membrane Filtration Method for Waters with Low Bacterial Background Flora-Amendment 1; (ISO 9308-1:2014/AMD 1:2016; EN ISO 9308-1:2014/AMD 1:2016); International Organization for Standardization: Geneva, Switzerland, 2014.

13. Baird, R.; Bridgewater, L. Standard Methods for the Examination of Water and Wastewater, 23rd ed.; American Public Health Association: Washington, DC, USA, 2017.

14. ISO 11731:2017. Water Quality_Enumeration of Legionella; International Organization for Standardization (ISO): Geneva, Switzerland, 2017.

15. ISO 6222:1999. Water Quality-Enumeration of Culturable Micro-Organisms-Colony Count by Inoculation in a Nutrient Agar Culture Medium; International Organization for Standardization (ISO): Geneva, Switzerland, 1999.

16. Standard Method 2550 B. Temperature of Water. Standard Methods for the Examination of Water and Waste Water, 23rd ed.; American Public Health Association (APHA): Washington, DC, USA, 2017.

17. ISO 7027-1:2016. Water Quality—Determination of Turbidity—Part 1: Quantitative Methods; International Organization for Standardization (ISO): Geneva, Switzerland, 2016.

18. ISO 7888:1985. Water Quality—Determination of Electrical Conductivity; International Organization for Standardization (ISO): Geneva, Switzerland, 1985.

19. ISO 7393-2:2018. Water Quality—Determination of Free Chlorine and Total Chlorine-Part 2: Colorimetric Method Using N,N-Diethyl-1,4Phenylenediamine, for Routine Control Purposes; International Organization for Standardization (ISO): Geneva, Switzerland, 2018.

20. ISO 10523:2008. Water Quality—Determination of pH.; International Organization for Standardization (ISO): Geneva, Switzerland, 2008.

21. ISO 10301:1997. Water Quality—Determination of Highly Volatile Halogenated Hydrocarbons—Gas-Chromatographic Methods; International Organization for Standardization (ISO): Geneva, Switzerland, 1997.

22. ISO 7150-1:1984. Water Quality—Determination of Ammonium—Part 1: Manual Spectrometric Method; International Organization for Standardization (ISO): Geneva, Switzerland, 1984.

23. ISO 9297:1989 Modified. Water Quality-Determination of Chloride-Silver Nitrate Titration with Chromate Indicator (Mohr's Method); International Organization for Standardization (ISO): Geneva, Switzerland, 1989.

24. ISO 10304-1:2007. Water Quality—Determination of Dissolved Anions by Liquid Chromatography of Ions-Part 1: Determination of Bromide, Chloride, Fluoride, Nitrate, Nitrite, Phosphate and Sulfate; International Organization for Standardization (ISO): Geneva, Switzerland, 2007.

25. Mena, K.D.; Gerba, C.P. Risk assessment of Pseudomonas aeruginosa in water. Rev. Environ. Contam. Toxicol. 2009, 201, 71-115. [CrossRef]

26. Anversa, L.; Arantes Stancari, R.C.; Garbelotti, M.; da Silva Ruiz, L.; Pereira, V.B.R.; Nogueira Nascentes, G.A.; Alves Dantas, S.T.; Mores Rall, V.L. Pseudomonas aeruginosa in public water supply. Water Pract. Technol. 2019, 14, 732-737. [CrossRef]

27. De Victorica, J.; Galván, M. Pseudomonas aeruginosa as an indicator of health risk in water for human consumption. Water Sci. Technol. 2001, 43, 49-52. [CrossRef]

28. Wen, X.; Chen, F.; Lin, Y.; Zhu, H.; Yuan, F.; Kuang, D.; Jia, Z.; Yuan, Z. Microbial indicators and their use for monitoring drinking water quality-A review. Sustainability 2020, 12, 2249. [CrossRef]

29. Camilla, B.; Daverio, E.; Michela, G. Microbiology Dimension in EU Water Directives; EUR 20787 EN. JRC25814; European Commission: Brussels, Belgium, 2003; Available online: https://publications.jrc.ec.europa.eu/repository/handle/JRC25814 (accessed on 20 September 2021).

30. World Health Organization (WHO). Heterotrophic Plate Counts and Drinking-Water Safety; IWA Publishing: London, UK, 2006; Available online: https://www.who.int/water_sanitation_health/dwq/HPCFull.pdf (accessed on 6 November 2021).

31. Moritz, M.M.; Flemming, H.-C.; Wingender, J. Integration of Pseudomonas aeruginosa and Legionella pneumophila in drinking water biofilms grown on domestic plumbing materials. Int. J. Hyg. Environ. Health 2010, 213, 190-197. [CrossRef]

32. Exner, M.; Kramer, A.; Lajoie, L.; Gebel, J.; Engelhart, S.; Hartemann, P. Prevention and control of health care-associated waterborne infections in health care facilities. Am. J. Infect. Control 2005, 33, S26-S40. [CrossRef] 
33. Loveday, H.P.; Wilson, J.A.; Kerr, K.; Pitchers, R.; Walker, J.T.; Browne, J. Association between healthcare water systems and Pseudomonas aeruginosa infections: A rapid systematic review. J. Hosp. Infect. 2014, 86, 7-15. [CrossRef]

34. Xue, Z.; Hessler, C.M.; Panmanee, W.; Hassett, D.J.; Seo, Y. Pseudomonas aeruginosa inactivation mechanism is affected by capsular extracellular polymeric substances reactivity with chlorine and monochloramine. FEMS Microbiol. Ecol. 2013, 83, 101-111. [CrossRef]

35. Official Gazette of the Republic of Croatia 125/2017 and 39/2020. Ordinance on Compliance Parameters and Methods of Analysis, Monitoring and Water Safety Plans of Water for Human Consumption and the Manner of Keeping a Register of Legal Entities Performing Public Water Supply Activities; Ministry of Health: Zagreb, Croatia, 2017.

36. Department of Health Estates \& Facilities. HTM 04-01-Addendum: Pseudomonas aeruginosa-Advice for Augmented Care Units. 2013. Available online: https://assets.publishing.service.gov.uk/government/uploads/system/uploads/attachment_ data/file/140105/Health_Technical_Memorandum_04-01_Addendum.pdf (accessed on 5 October 2021).

37. The French Society for Hospital Hygiene (SFHH). Recommandations Nationales. Préventionde la Transmission Croisée: Précautions Complémentaires Contact. 2009. Available online: https://www.sf2h.net/wp-content/uploads/2009/01/SF2 H_prevention-transmission-croisee-2009.pdf (accessed on 18 October 2021).

38. Official Gazette of the Republic of Montenegro 24/2012 and 32/2015. The Rulebook on Detailed Safety Requirements for Drinking Water; Ministry of Health: Podgorica, Montenegro, 2012; Available online: http:/ /www.podaci.net/_gCGO/propis/Pravilnik_o_ blizim/P-bzpbti04v1224.html (accessed on 20 November 2021).

39. Official Gazette of the Federation of Bosnia and Herzegovina 40/10; 43/10; 30/12 and 62/2017. Regulation on Health Safety of Drinking Water; Official Gazette of the Federation of Bosnia and Herzegovina: Sarajevo, Bosnia and Herzegovina, 2010.

40. Official Gazette of the Republic of Slovenia 19/04; 35/04; 26/06; 92/06; 25/09; 74/15; 51/17. Rules on Drinking Water; Uradni List Republike Slovenije: Ljubljana, Slovenia, 2004.

41. U.S. Environmental Protection Agency (U.S. EPA). National Primary Drinking Water Regulations. Microorganisms. 2017. Available online: https:/ / www.epa.gov / ground-water-and-drinking-water/national-primary-drinking-water-regulations\# Microorganisms (accessed on 22 August 2021).

42. Hardalo, C.; Edberg, S.C. Pseudomonas aeruginosa: Assessment of risk from drinking water. Crit. Rev. Microbiol. 1997, 23, 47-75. [CrossRef]

43. Firuzi, P.; Asl Hashemi, A.; Samadi Kafil, H.; Gholizadeh, P.; Aslani, H. Comparative study on the microbial quality in the swimming pools disinfected by the ozone-chlorine and chlorine processes in Tabriz, Iran. Environ. Monit. Assess. 2020, $192,516$. [CrossRef]

44. Hajjartabar, M. Poor-quality water in swimming pools associated with a substantial risk of otitis externa due to Pseudomonas aeruginosa. Water Sci. Technol. 2004, 50, 63-67. [CrossRef]

45. Abd El-Salam, M.M. Assessment of water quality of some swimming pools: A case study in Alexandria, Egypt. Environ. Monit. Assess. 2012, 184, 7395-7406. [CrossRef]

46. Aboulfotoh Hashish, N.M.; Gawad Abbass, A.A.; Khamis Amine, A.E. Pseudomonas aeruginosa in swimming pools. Cogent Environ. Sci. 2017, 3, 1328841. [CrossRef]

47. Dallolio, L.; Belletti, M.; Agostini, A.; Teggi, M.; Bertelli, M.; Bergamini, C.; Chetti, L.; Leoni, E. Hygienic surveillance in swimming pools: Assessment of the water quality in Bologna facilities in the period 2010-2012. Microchem. J. 2013, 110, 624-628. [CrossRef]

48. Moore, J.E.; Heaney, N.; Millar, B.C.; Crowe, M.; Elborn, J.S. Incidence of Pseudomonas aeruginosa in recreational and hydrotherapy pools. Commun. Dis. Public Health 2002, 5, 23-26.

49. Wei, X.; Li, J.; Hou, S.; Xu, C.; Zhang, H.; Atwill, E.R.; Li, X.; Yang, Z.; Chen, S. Assessment of microbiological safety of water in public swimming pools in Guangzhou, China. Int. J. Environ. Res. Public Health 2018, 15, 1416. [CrossRef]

50. Croatian Bureau of Statistic. CBS Databases. 2021. Available online: https://www.dzs.hr (accessed on 15 August 2021).

51. Papadopoulou, C.; Economou, V.; Sakkas, H.; Gousia, P.; Giannakopoulos, X.; Dontorou, C.; Filioussis, G.; Gessouli, H.; Karanis, P.; Leveidiotou, S. Microbiological quality of indoor and outdoor swimming pools in Greece: Investigation of the antibiotic resistance of the bacterial isolates. Int. J. Hyg. Environ. Health 2008, 211, 385-397. [CrossRef]

52. World Health Organization (WHO). Guidelines for Safe Recreational Water Environments. Volume 2 Swimming Pools and Similar Environments; WHO: Geneva, Switzerland, 2006.

53. Ujević Bošnjak, M.; Gajšak, F.; Antičević, M.; Štiglić, J. Pool water safety in Republic of Croatia in year 2017. In Proceedings of the XXII Scientific and Professional Conference Water and Public Water Supply, Sisak, Croatia, 2-5 October 2018; pp. 23-31.

54. Ríos-Castillo, A.G.; González-Rivas, F.; Rodríguez-Jerez, J.J. Bactericidal efficacy of hydrogen peroxide-based disinfectants against gram-positive and gram-negative bacteria on stainless steel surfaces. J. Food. Sci. 2017, 82, 2351-2356. [CrossRef]

55. Borgmann-Strahsen, R. Comparative assessment of different biocides in swimming pool water. Int. Biodeterior. Biodegrad. 2003, 51, 291-297. [CrossRef]

56. Centers for Disease Control and Prevention. The Model Aquatic Health Code ANNEX Draft Posted for Public Comment. Disinfection and Water Quality 2012. Available online: https://www.cdc.gov/healthywater/pdf/swimming/pools/mahc/ structure-content/mahc-disinfection-water-quality-annex.pdf (accessed on 20 November 2021).

57. Rice, S.A.; van den Akker, B.; Pomati, F.; Roser, D. A risk assessment of Pseudomonas aeruginosa in swimming pools: A review. J Water Health 2012, 10, 181-196. [CrossRef] 
58. Corre, M.-H.; Delafont, V.; Legrand, A.; Berjeaud, J.-M.; Verdon, J. Exploiting the richness of environmental waterborne bacterial species to find natural Legionella pneumophila competitors. Front. Microbiol. 2019, 9, 3360. [CrossRef]

59. Borella, P.; Montagna, M.T.; Romano-Spica, V.; Stampi, S.; Stancanelli, G.; Triassi, M.; Neglia, R.; Marchesi, I.; Fantuzzi, G.; Tatò, D.; et al. Legionella infection risk from domestic hot water. Emerg. Infect. Dis. 2004, 10, 457-464. [CrossRef]

60. Leoni, E.; Legnani, P.P.; Bucci Sabattini, M.A.; Righi, F. Prevalence of Legionella spp. in swimming pool environment. Water Res. 2001, 35, 3749-3753. [CrossRef]

61. Bilajac, L.; Vukić Lušić, D.; Doko Jelinić, J.; Rukavina, T. Microbiological and chemical indicators of water quality in indoor hotel swimming pools before and after training of swimming pool operators. J. Water Health 2011, 10, 108-115. [CrossRef] [PubMed]

62. Official Gazette of the Republic of Croatia 59/2020. Regulation on Sanitary-Technical and Hygienic Conditions of Swimming Pools and on the Health Safety of Pool Waters; Ministry of Health: Zagreb, Croatia, 2020.

63. Official Gazette of the Republic of Serbia 30/2017 and 97/2017. The Rulebook on Swimming Pool Water Quality; Ministry of Health: Belgrade, Serbia, 2018.

64. Official Gazette of the Republic of Montenegro 57/2018 and 112/2020. Regulation on Sanitary-Technical and Hygienic Conditions, as Well as Conditions for Health Safety of Water for Recreational Needs and Other Waters of Public Health Interest; Ministry of Health: Podgorica, Montenegro, 2018.

65. Official Gazette of the Federation of Bosnia and Herzegovina 50/2018. Regulation on Sanitary-Technical and Hygienic Conditions of Swimming Pools and Health Safety of Pool Waters; Ministry of Health: Sarajevo, Bosnia and Herzegovina, 2018.

66. Official Gazette of the Republic of Slovenia 59/15; 86/15 and Amendments 52/18. Rules on the Minimum Hygiene Requirements for Bathing and Bathing Water in Swimming Pools; Ministry of Health: Ljubljana, Slovenia, 2015.

67. American National Standards Institute. American National Standard for Water Quality in Public Pools and Spas ANSI/APSP/ICC-11 2019; American National Standards Institute: Washington, DC, USA, 2020; Available online: https:/ issuu.com/thephta/docs/ apsp-11_2019 (accessed on 6 November 2021). 